\title{
THE DIGITAL:
}

FROM COMPLEXITY TO SIMPLICITYAND BACK ${ }^{1}$

\section{A B S T R A C T}

At the beginning of the digital turn, in the early 1990s, digitally intelligent architecture was generally perceived as curvilinear, smooth, and streamlined. Why? Computers are extraordinarily versatile machines, and they do not express aesthetic preferences. It is evident that this is not what Peter Eisenman, who was among the inventors of the first digital style in the 1990s, then had in mind. And why is it that today the style of digitally intelligent architecture appears to be changing again?

These are (some) issues addressed in this short paper questioning why and how the digital as a tool engages, masters and produces complexity. 
I would start with a very simple question. Why is it that at the very beginning of the digital turn, back in the early 1990s, when Peter Eisenman first started to think of a "new architecture for the age of electronic media", digitally intelligent architecture was meant to look complex, fractured, disjointed, angular and fragmentary (fig. 1,2,3); why is it that soon thereafter digitally intelligent architecture started to look smooth, sinuous, curvilinear and streamlined (fig. $4,5,6,7,8,9)$; and why is it that today, the new digital avant-garde increasingly looks rough, messy, aggregatory or chaotic (fig. 10,11,12) - i.e. quite different from what first Peter Eisenman and then Greg Lynn, respectively, had in mind? Evidently, the style of digitally intelligent architecture has changed in the course of the last twenty years. Historians, like myself, would be curious to know why.

The earlier part of this story is well known, and it has been studied at length. It is the story of the architectural re-invention of the Deleuzian fold, from Deleuze's books The Fold, Leibniz and the Baroque, first published in France in 1988, which would inspire a seminal issue of AD, guest-edited by Greg Lynn in 1993, with major contributions by Eisenman himself Eisenman's Deconstructivist buildings of the time, due to their geometrical complexity, already required the use of some electronic tools, particularly for measurements and on site construction. Consequently, Eisenman then saw electronics as a means to his end, and a Deconstructivist weapon of choice; electronics could supply new "strategies for dislocating vision," to "break the gridded space of the Cartesian order;" for the same reason, Eisenman then also saw the forthcoming digital fold as a continuation of Deconstructivism with electronic means. Electronics, and the Deleuzian Fold, would not only support but extend, amplify, and vindicate the complexity and fragmentation of Eisenman's own Deconstructivist style.

As we now know, it did not work that way. Greg Lynn's seminal essay on Folding in Architecture defined the Deleuzian fold as a curve, not as an angle; and in the same essay Lynn argued for the design of curves of all sorts, and for many different reasons - but first and foremost to reconcile the opposition between the abstract angles of Eisenman's Deconstructivism and the iconic figuration of architectural post-modernism. Of course, it helps to remember in this context that Deleuze's fold, originally, was indeed a curve: and a very particular curve, as Deleuze defined the Fold as the point of inflexion in a continuous function, as determined by Leibniz's differential calculus. As we now know, the Deleuze connection in architecture in the 1990s was in many ways a direct link, via Deleuze, to Leibniz and Newton's mathematics of continuity, which around that time computers started to make easily accessible 


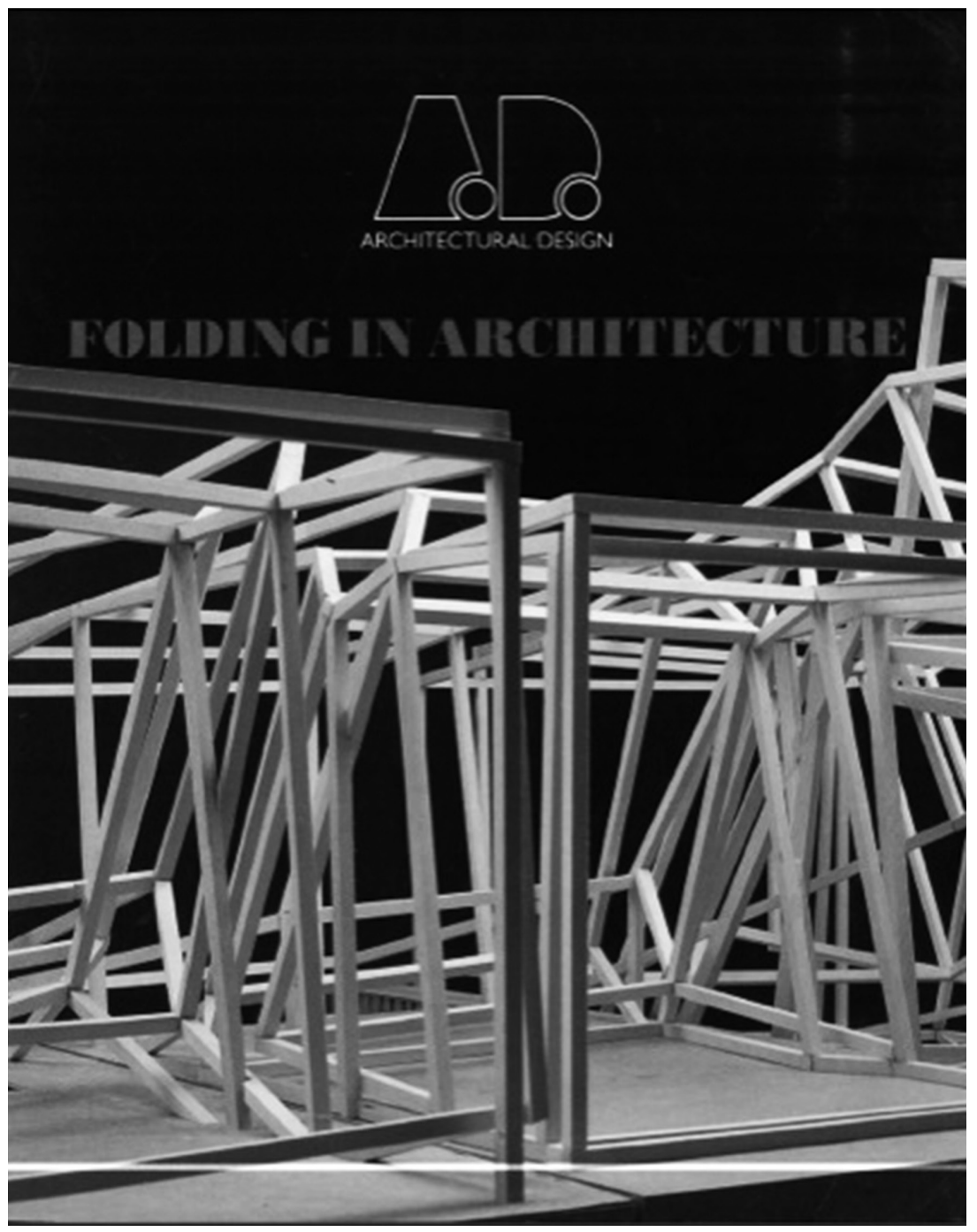

Figure 1. Peter Eisenman, Center for the Arts, Emory University, Atlanta, 1991, from the cover of Architectural Design 63, 1993, 3-4, Profile 102: Folding in Architecture, edited by Greg Lynn. 
and usable to many that did not necessarily have an expert mathematical training. Greg Lynn's curving Stranded Sears Towers (fig. 13,14), published in Folding in Architecture in 1993, were entirely drawn by hand; but only a few years later, Greg Lynn and Bernard Cache could famously argue that, thanks to computers, calculus had become, for the first time ever, a practical tool for design and fabrication. Calculus means continuity and continuous functions; hence, evidently, curves - not angles.

As it happens, the Trojan horse whereby differential calculus pervaded the first age of digitally intelligent architecture was not calculus as such, but a later application of calculus embedded in a new generation of software, known as spline modelers. As every user of computer graphics, animation software and computer aided design today knows, spline modelers are that magic tool that can join together every cluster of points on a computer screen with a perfectly smooth continuous line, and can likewise transform and convert every uncertain doodle or random stroke of the hand into an equally smooth and perfect curve. Indeed, the lines made by spline modelers are so smooth and clean and perfect that sometimes they do not even seem to belong to the natural world in which we live, and in fact they don't: they come and visit us, as it were, from another supernatural world which they inhabit, the world of geometrical objects, which, since the beginning of Western philosophy, since Plato and Euclid, is normally held to be quite distinct from the phenomenological world in which we live.

Splines are so smooth and perfect because they are scripted as continuous, parametric functions. The use of differentials and infinitesimals to describe variations in a continuous curve was the great invention of Leibniz's and Newton's calculus, and the mathematics of splines, aka NURBS (non-uniform, rational, B-Splines) was developed in the late 1950s and in the early 1960s by two French engineers, Pierre Bézier and Paul de Casteljau, working, respectively, for two carmakers in Paris - Renault and Citroën. A few years apart, Bézier and de Casteljau found two slightly different mathematical ways to join some fixed geometrical points with a smooth continuous line, called in English a "spline." The English term derives from the traditional craft of shipbuilders, but the novelty of Bézier's and De Casteljau's mathematical splines was that they found a way to notate those lines as a parametric functions, so that the lines could be recorded and transmitted as a mere sequence of letters and numbers, and when necessary edited and tweaked by giving different number values to some parameters. In turn, the great novelty of the early 1990s was that spline modelers included in early software for computer aided design, such as Form $\mathrm{Z}$ and Rhino, made some of that mathematics easily available to all, not through number-based operations, but through interactive graphic user 


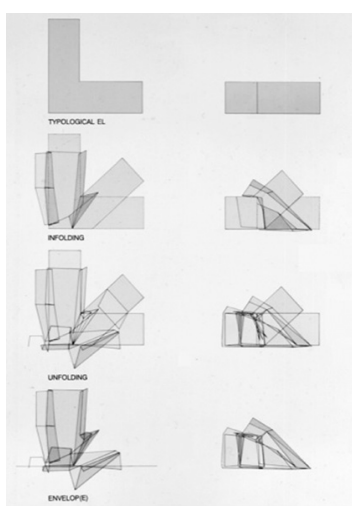

Figure 2. Peter Eisenman, Alteka Office Building, Tokyo, 1991.

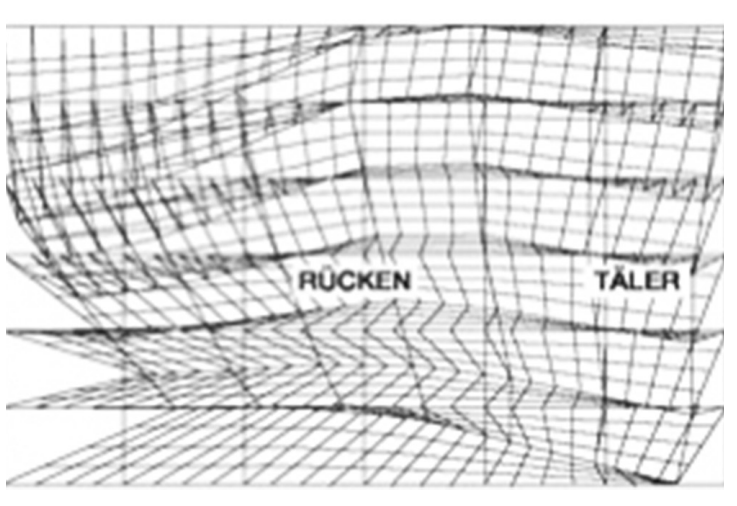

Figure 3. Peter Eisenman, Rebstock Park Masterplan, Frankfurt, Germany, 1990-91

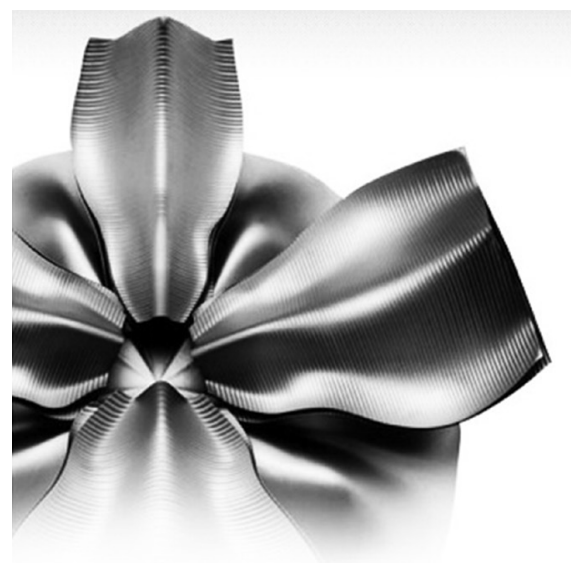

Figure 4. Greg Lynn FORM, Alessi Coffe and Tea Piazza, 2000

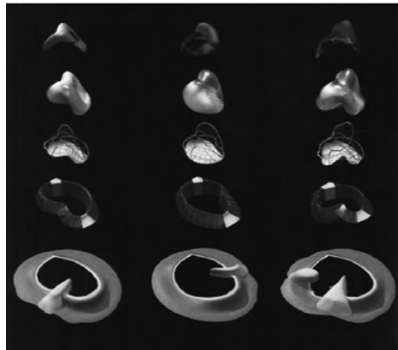

Figure 5. Greg Lynn FORM, Embryological House, 1997-2001

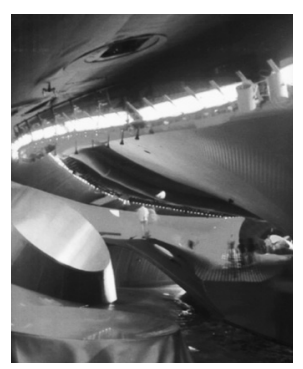

Figure 6. Nox/Lars Spuybroek, Fresh Water Pavilion, 1994-97

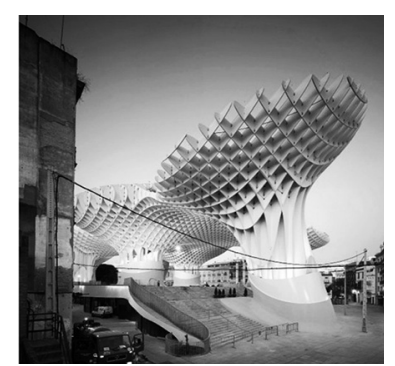

Figure 7. Jürgen Meyer, Metropol Parasol, Seville, 2005-11 
interfaces: control points and vectors that everyone could easily edit, move and drag on the screen by the click of a mouse. As that game turned out to be faster and more intuitive than the high-school calculus on which it was based, spline modelers soon became hugely popular among the first generation of digital designers. In short, this is how the architecture of the first digital age turned out to be a calculus-based, spline-dominated environment - and the style of the first digital age turned out to be curvilinear, not angular.

Assuredly, not every digitally intelligent designer in the 1990s was a spline maker: Frank Gehry, for example, used computers to scan, measure, notate and build irregular, non geometrical three-dimensional shapes. But the divide between "free form" and mathematical splines is often a tenuous one, and is not easily assessed visually; if one just looks, what one sees is mostly sweeping, spline-like curves - and indeed this is what most saw at the time, wherever and whenever digital design and fabrication were employed - or implied.

Fast forward to today. In the course of the last twenty years, many of the pioneering ideas of the digital avant-garde have been remarkably successful; and some have gone mainstream. Last winter, US President Barak Obama in his yearly State of the Union address mentioned 3D printing as a revolutionary new technology that has the potential to change "the way we make almost everything." Digital mass-customization is indeed much cheaper today than it was twenty years ago, and it is certainly a matter of some satisfaction for us, in the design professions, to see that the ideas and intuitions of small group of visionary designers in the early 1990s are now being discussed by global leaders and decision makers around the world. In twenty years from Gilles Deleuze to the White House - this is something of an achievement that the design professions can be proud of. For these were originally our ideas (Peter Eisenman's and Greg Lynn's and Bernard Cache's and a few others'); this was our stuff - and these ideas are already changing the world in which we live.

So it would appear that 20 years ago we were right - good. But, if so, why is it that today's digital style appears to be changing once again? Why would we leave behind the spline-dominated environment of the first digital turn to embrace what appears to be a new style of digital disorder, messiness, complexity, patchiness, disjointedness, and even - once again - angularity and aggregation? This is a matter of some importance, because, if that indeed were happening, we would be, in a sense, almost going back to where it all started, namely: to the digital as a tool to engage, master, and produce complexity hence, indeed, to where Peter Eisenman stood around 1992. The spline and calculus are quintessential expressions of modern mathematics, and as such 


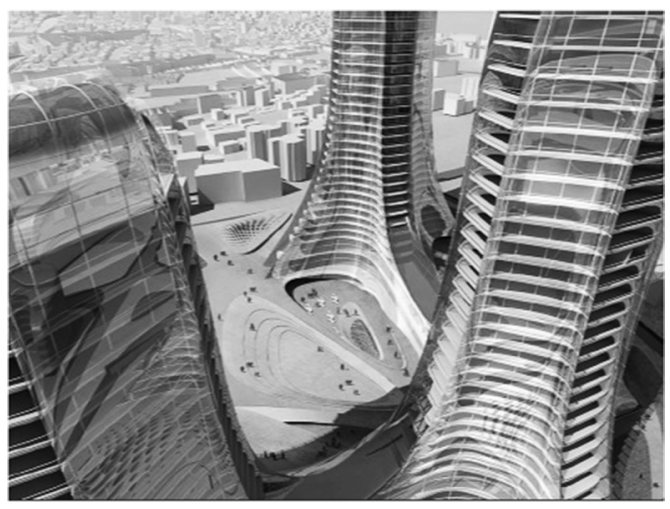

Figure 8. Zaha Hadid Architects, Kartal Pendik Masterplan, Istanbul, 2006

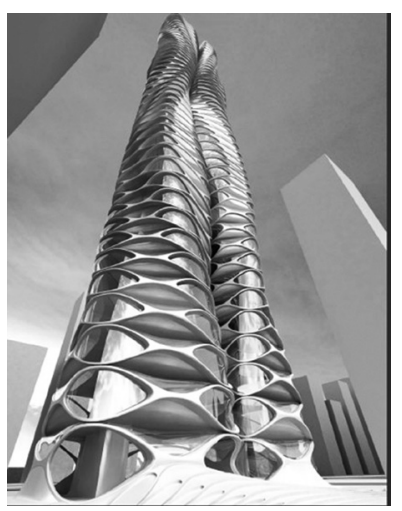

Figure 9. Ali Rahim, Hina Jamelle, Residential Tower, Dubai, 2005.

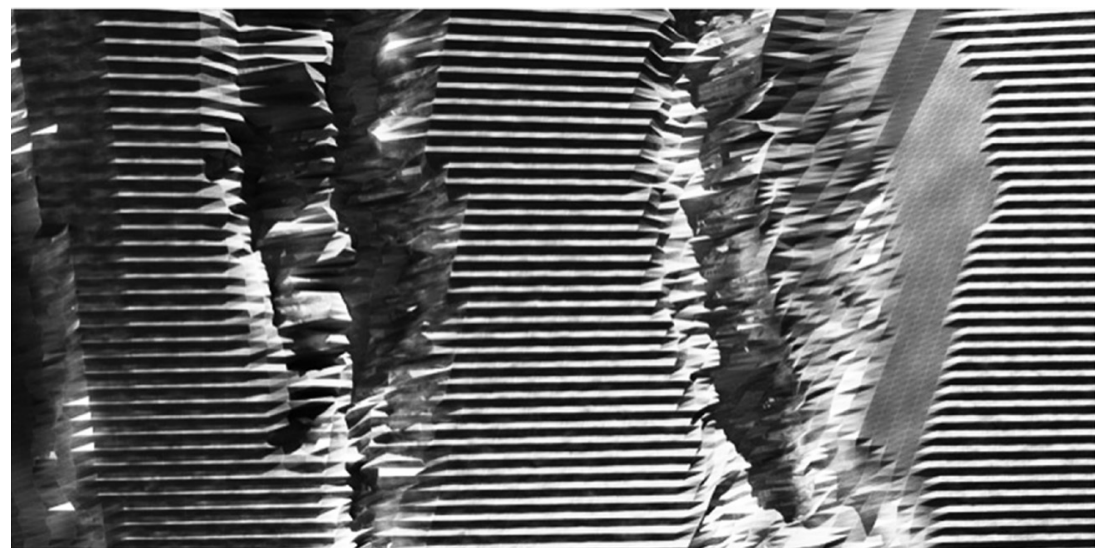

Figure 10. Alisa Andrasek/Biothing, Fissure Port Terminal, Kaohsiung, Taiwan, 2010

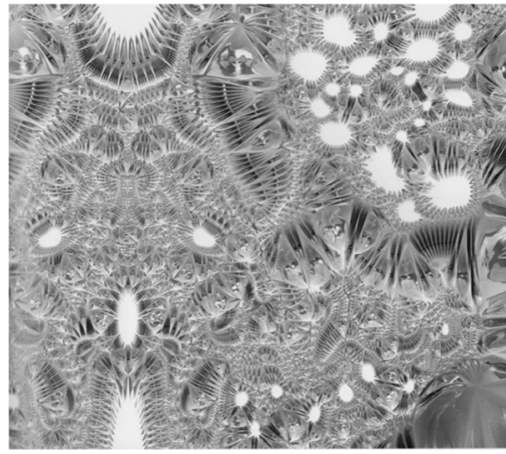

Figure 11. Ruy Klein, Klex, 2011

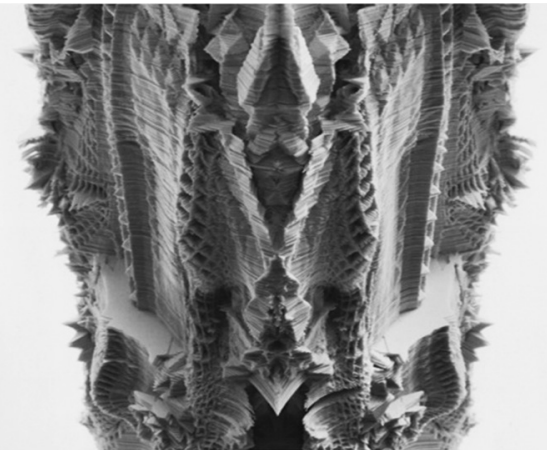

Figure 12. Michael Hansmeyer, Benjamin Dillenburger, Digital Grotesque Grotto, FRAC Orléans, 2013 
they are tools of simplicity, not of complexity: modern calculus simplifies variations so we can script and calculate them; and digital splines produce forms of splendidly smooth and elegantly streamlined simplicity. And it would appear that this is exactly what we are now leaving behind.

But why? This is not really the subject of this paper, and I have only a few minutes left, so let me just hint at a couple of points as a way to open up the discussion.

First: alongside the Deconstructivist roots I just mentioned, from the 1990s to this day, digital theory in general, and digital design theory in particular, have been deeply marked by theories and beliefs of post-modern provenance, and tinted by a strong indeterminist, phenomenological, spiritualistic, or even vitalistic orientation. Some of these theories derive somehow from late-modern system theory, complexity theory, and from the so-called postmodern sciences of indeterminacy and "non-linearity". In the 90s these were the extreme but marginal views of a group of radical thinkers and ideologues, albeit trendy at times, particularly in some circles. But today, many of these theories have been vindicated by techno-social change - probably beyond the wildest expectations of their post-modern prophets. Post-modern philosophers tended to be vaticinatory, obscure, disgruntled, and often apocalyptic. Today, their visions have been turned into reality by a bunch of high-tech start-ups and by a new generation of adolescent entrepreneurs, most of whom may have never heard the names of Gilles Deleuze or Ilya Prigogine. Indeterminacy and non-linearity are now staples of our daily digital lives, and they have already infiltrated many of our new, technologically driven social practices, our economic behavior, and even science.

Some digitally intelligent designers, in my opinion, are simply taking notice. As the tools we use inevitably feedback on the things we make, today's digital style is increasingly representing the heuristic and holistic logic of today's new digital indeterminacy - as a metaphor and image as well as a material index or trace of this novel, and at the same time very old, and ancestral, way of making. This is why today's digital style looks messy and rough - this is the way Big Data looks, because we have no clue how to interpret them; and this is the way digital computation works, even if we often cannot say why, or how. Twenty years ago, Peter Eisenman thought that digital tools would help him deal with, and express, complexity. After twenty years of spline-driven smoothness and simplification, it now appears that he may have been quite right back then - perhaps just a tad too early. 

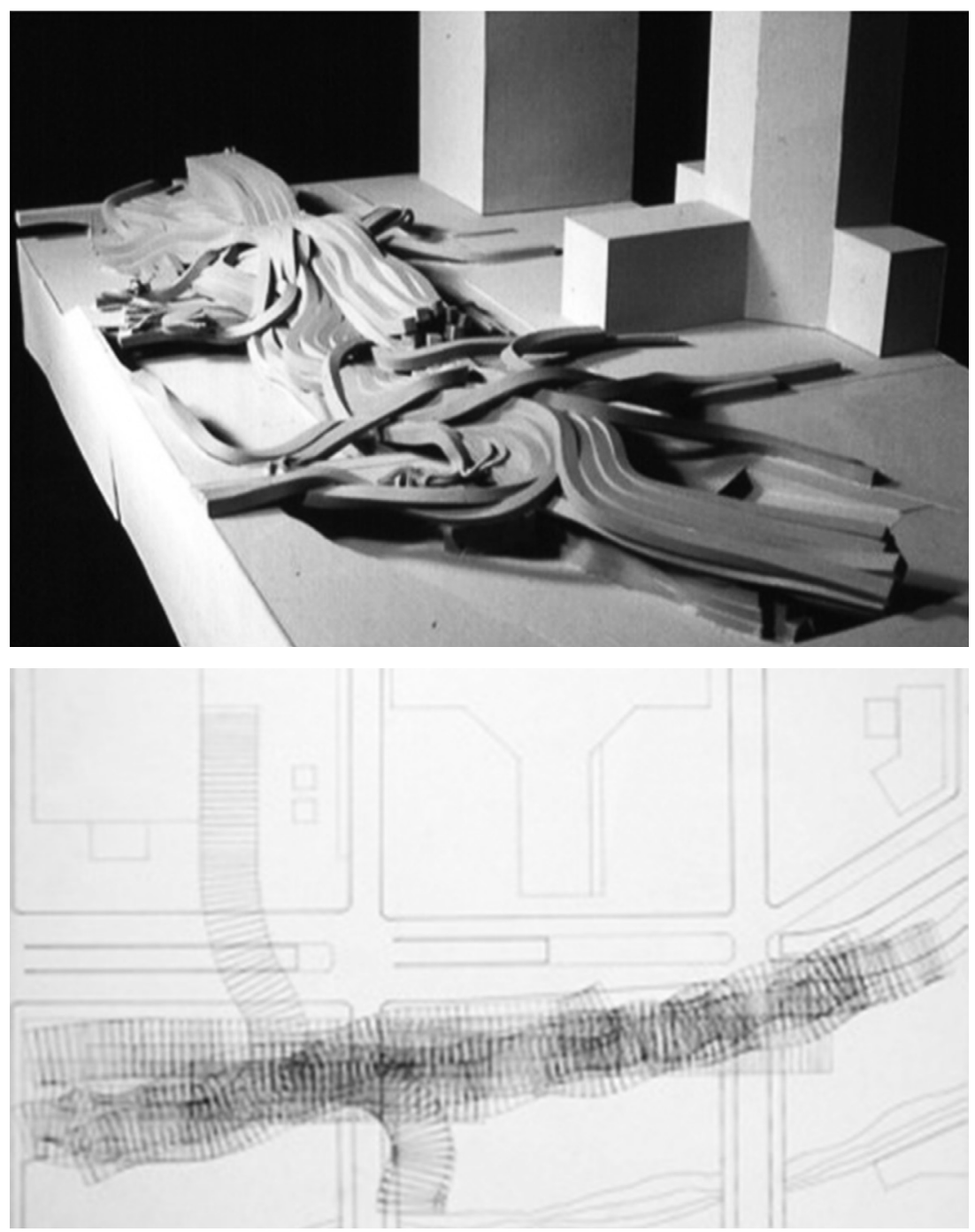

264

Figure 13-14. Greg Lynn, Stranded Sears Towers, Chicago, 1992 
This is the text of a paper read at the conference Issues? Concerning the Project of Peter Eisenman, organized by Faculty of Architecture of the University of Belgrade, Serbia, on 11-12 November 2013. It is published here with some revisions and corrections but in the format and style of the oral delivery for which it was meant. For footnotes and further reference see:

Mario Carpo, "Introduction," in The Digital Turn in Architecture, 1992-2012. An AD Reader (Chicester: Wiley, 2012), 8-15.

Mario Carpo, The Alphabet and the Algorithm (Cambridge, MA and London, England: The MIT Press, 2011, 83-93.

Mario Carpo, "Digital Darwinism," Log 26 (2012): 97-105.

Mario Carpo, "Digital Style," Log 23 (2011): 41-52.

Mario Carpo, "Breaking the Curve. Big Data and Digital Design," Artforum 52, 6 (2014): 168-173.

Carpo, Mario. "Introduction." In The Digital Turn in Architecture, 1992-2012. An AD Reader, 8-15. Chicester: Wiley, 2012.

Carpo, Mario. The Alphabet and the Algorithm. Cambridge, MA and London, England: The MIT Press, 2011.

Carpo, Mario. "Digital Darwinis.” Log 26 (2012): 97-105.

Carpo, Mario. "Digital Style.” Log 23 (2011): 41-52.

Carpo, Mario. "Breaking the Curve. Big Data and Digital Design." Artforum 52, 6 (2014): 168173. 


\section{PITER AJZENMAN,}

\section{ILI KAKO ELIMINISATI ONO ŠTO ČOVEK POSTANE}

\section{Jörg H. Gleiter}

Piter Ajzenman je Ikar post-avangardne arhitekture koji se može pohvaliti brojnim visoko cenjenim, kontroverznim objektima - kao što su Spomenik ubijenim Jevrejima Evrope u Berlinu i Ciudad de la Cultura de Galicia u Santijagu de Kompostela. Kako eliminisati ono što čovek postane-ovo je jedan od načina da se rezimira jedna od presudnih odlika Ajzenmanove arhitektonske prakse: nestanak autora. Pokazujući svoj prezir prema individualnom stilu u umetnosti, Ajzenman je u debatama o arhitekturi redovno potezao pitanje Mišela Fukoa: „Šta je pisac?” Međutim, smrt autora - „la mort de l'auteur” koju je prvi put pomenuo Roland Bart - nije bila sama sebi svrha po Ajzenmanu. Zato što jedino pitanje koje sledi:,Šta je kritika?”, osvetljava ulogu eliminacije autora u negativnosti estetike Ajzenmanove arhitektonske prakse: to je dijalektika kritike razuma i epistemologije. U tom smislu, Ajzenmanova teorija arhitekture predstavlja važan-ako ne nekontroverzan-doprinos kritičkoj filozofiji arhitekture.

KLJUČNE REČI: PITER AJZENMAN, FILOZOFIJA ARHITEKTURE, KRITIČKA TEORIJA, AUTORSTVO, DEKONSTRUKCIJA, PROJEKTOVANJE

OPERATIVNE RAZLIKE.

\section{AJZENMAN, TAFURI I LEKCIJA PIRANEZIJA}

\section{Gabriele Mastrigli, Alessandro Toti}

Piter Ajzenman je arhitekta. Iako povezana sa interesovanjem za razne oblike, oblast njegovog delovanja obuhvata istraživanje teorijskog osnova arhitektonske discipline. Arhitektura, kao artefakt i kao projekat, može da se posmatra kao najočiglednija reprezentacija tradicionalne opozicije zapadne metafizike: odsustva i prisustva. Stoga je zadatak arhitekte, prema Ajzenmanu, da analitički interveniše u ovom dijalektičkom stanju i učini ga operativnim.

Sa ove tačke gledišta, Ajzenmanov pristup disciplini - kao i čitav njegov, celoživotni arhitektonski razvojni put - posmatra se u svetlu dela Đovanija Batiste Piranezija. Otišavši dalje od kritike italijanskog istoričara arhitekture Manfreda Tafurija, Ajzenman je istraživao mogućnost novog tumačenja dijalektike između pozitivnog i negativnog, izbravši pojam zemljišta kao samog mesta ove opozicije. Berlinski Spomenik ubijenim Jevrejima Evrope nudi konačnu reprezentaciju ove dijalektike, čime otvara mogućnost daljeg, neuporedivog rada na njoj.

KLJUČNE REČI: ARHITEKTURA, RAZLIKE, ANALIZA, PROJEKAT, DIJALEKTIKA, REPREZENTACIJA, JEZIK, MONTAŽA, TRAG, ZEMLJIŠTE, SUBJEKT. 
DIGITALNO :

OD KOMPLEKSNOSTI DO JEDNOSTAVNOSTI - I NATRAG

\section{Mario Carpo}

Na početku digitalnog prevrata u ranim 90-tim godinama, digitalno inteligentna arhitektura je uopšteno smatrana krivolinijskom, oblom i modernom. Zašto? Računari su izuzetno svestrane mašine, ali koje ne pokazuju estetičke preferencije. Svakako da Piter Ajzenman, koji je jedan od izumitelja digitalizovanog pravca i 90-tim, nije imao ovo na umu. I zašto se danas stil/pravac digitalno inteligentne arhitekture ponovo menja?

Ovo su (neka od) pitanja koja su obrađena u ovom kratkom radu koji ispituje zašto i kako digitalno kao alat uključuje, ovladava i proizvodi kompleksnost.

KLJUČNE REČI: DIGITALNO, SPLAJNOVI / KRIVE, ALAT, KOMPLEKSNOST, AJZENMAN

\section{ŠTA JE ARHITEKTONSKO ISTRAŽIVANJE DANAS \\ I GDE JE OSNOV?}

\section{Djordje Stojanović}

Zašto graditi velike objekte od gumica sa studentima arhitekture? Na koji način je taj poduhvat povezan sa arhitektonskim obrazovanjem? I ako objekti od gumica nisu ni zgrade, ni modeli, već neka vrsta eksperimenata, kakvu vrstu znanja relevantnog za građevinsku industriju i izgrađeno okruženje oni generišu? Ovo su neka od pitanja koja su postavljena na konferenciji "ISSUES? Concerning the projects of Peter Eisenman" /PITANJA? U vezi sa projektima Pitera Ajzenmana/ koja je održana u Beogradu, u novembru 2013. Ona su povezana sa nizom projektantskih istraživačkih projekata koji su nedavno završeni na Arhitektonskom fakultetu, Univerziteta u Beogradu, i koji su dokumentovani u tematskom izdanju Srpskog arhitektnoskog žurnala pod naslovom „Arhitektonsko obrazovanje u postdigitalnom dobu” koje je objavljeno nezavisno od, ali skoro istovremeno sa održavanjem konferencije. U skladu sa argumentima iznetim u toj publikaciji, ovaj rad će prikazati neke od relevantnih i opšteprihvaćenih teorija i manifesta koji se odnose na metodologije projektantskog istraživanja, pružajući osnov za tekući rad na Arhitektonskom fakultetu, Univerziteta u Beogradu.

KLJUČNE REČI: ARHITEKTONSKO ISTRAŽIVANJE, UMETNIČKO ISTRAŽIVANJE, ISTRAŽIVANJE KROZ PROJEKAT, ISTRAŽIVANJE ZASNOVANO NA PRAKSI 